\title{
A study on the relationship of Facebook and EFL learners' personality
}

Wang, Chi Yuan

Lunghwa University of Science and Technology, Taiwan, ROC (lead0409@yahoo.com.tw)

Ching, Gregory S.

Graduate School of Educational Leadership \& Development, Fu Jen Catholic University, Taiwan, ROC (gregory_ching@yahoo.com)

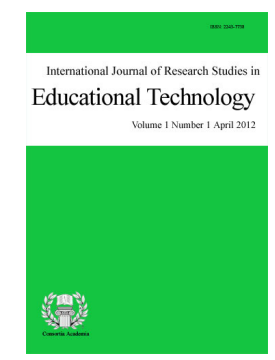

ISSN: $2243-7738$ Online ISSN: 2243-7746

OPEN ACCESS

Received: 15 December $2012 \quad$ Revised: 27 June $2013 \quad$ Accepted: 18 July 2013 Available Online: 1 August $2013 \quad$ DOI: 10.5861 /ijrset.2013.434

\section{Abstract}

Social networking software or what people are more familiar with "Facebook" has truly affected each and every person in the world. More so with students, Facebook has already become part of their daily activities. In an English as a Foreign Language (EFL) setting, it is quite interesting if students would also spend the same time and effort in learning a foreign language. With this in mind, the current study describes the various background factors regarding students' use of Facebook in a science and technology university in Taiwan. Similarly, the Big Five Personality inventory is also use to further describe the inherent factors that influence students' Facebook use and behaviors. Participants are 132 volunteer EFL students. Statistical analysis shows that most EFL students are link to the personality trait "Openness". While freshmen students tend to be emotionally less stable compared to the other participants from higher years. With regards to the students' Facebook habits, results show that students on average spend around 15 minutes twice a day browsing the site. Interestingly students who are emotionally less stable tend to spend more time on Facebook and possess a larger number of member communities. In sum, Facebook has brought forth numerous opportunity for students to become more engaged within a community. It is recommended that such scenario should be adapted more effectively in language learning, hence, achieve a more interactive approach to learning.

Keywords: social networking sites; Facebook; personality; behavior; time-spent online 


\section{A study on the relationship of Facebook and EFL learners' personality}

\section{Introduction}

In recent years, Facebook has changed the way people perceived online communities (Blattner \& Fiori, 2011; Thomas, 2011). This is more evident with the recent rise in popularity of Social Networking Sites (SNS). Currently, students' perspectives on citizenship have all together changed (Thomas, 2011). It is noted that the concepts of citizenship is always tied to a community; SNS learning environment in itself is a digital community (Ohler, 2010). With Facebook having around 800 million active users; SNS has indeed changed the way how people interacts with each other (Facebook, 2011). In Taiwan, data from the August 2011 survey mentioned that on average, an individual spends around 27.8 hours online per month (China Times, 2011). Results also show that Facebook accounts for $27 \%$ of the time, while YouTube accounts for around $4 \%$ of the time. Data also suggests that there is an overall increase of around $24 \%$ as compared to last year's average. In sum, the number and time spend of online users would only increase with the further advancement of technology. Hence, it is quite important to determine the extent of Facebook use in our schools today.

In light of these issues, this case study summarizes the findings of a project focusing on understanding the factors influencing the students' Facebook use. In addition, this study also uses the Big Five Inventory to determine the participants' personality and compares them to their Facebook habits.

\subsection{Research questions}

With a primary objective of understanding the participants' Facebook habits, initial research questions are generated as follows:

a. What are the common Facebook habits of the students?

b. What factors influence the students' Facebook habits?

c. What is the relationship between the students' personality and their Facebook habits?

\subsection{Significance of the study}

Recently, much concern regarding the students' Facebook habits have been seen. Educators are concerned that the students' Facebook habits might affect their overall learning development. Hence, this study is able to provide various important implications not only to the academic community, but for the society as well.

a. The study opens up new ways of understanding why students act the way they are.

b. The study also provides various implications regarding the effects of demographical factors towards the students' Facebook habits.

c. More importantly, the current study is able to provide insights on the various issues on Facebook usage.

\section{Literature review}

\subsection{Social Networking Sites (SNS) and learning}

Social networks are actually defined as the social structure of nodes that represent individuals (or organizations) and the relationships between them within a certain domain. Therefore, social networks are 
usually built based on the strength of relationships and trust between the members (nodes) (Liccardi et al., 2007, p. 225). Recently many have been using the concept of SNS in the educational settings. In a study on high school students' online community discussion forum, wherein students provide comments or expressed their thoughts and opinions on blogs. Results show that such social talks are able to help solved collaborative issues in a subtle and indirect manner, hence, makes learning more effective (Chen \& Wang, 2009).

SNS adaptation in a language learning program has also shown to have positive outcomes. More specifically, SNS help promotes learner-learner interaction and the development of cross-cultural identities (Reinhardt \& Zander, 2011). While a study involving the use of Facebook in increasing the students' competency; a linguistic analysis was incorporated focusing on greetings, leave-takings, and vocabulary selection. Results show that learners learn in a socio-pragmatic paradigm, in a way students improved by observing how others accomplished a given task (Blattner \& Fiori, 2011). Other studies regarding Facebook have also shown that SNS are able to promote learning as long as activities are monitored by their teacher (Rouis, Limayem, \& Salehi-Sangari, 2011), while students' are able to improve on their English vocabulary knowledge through periodic Facebook entries in English (Wang, Sheu, \& Masatake, 2011).

In a study on a Taiwanese network learning society "EduCities"; findings suggest a structured network learning society helps participants coordinate and manage interaction processes (Chang, Cheng, Deng, \& Chan, 2007). In a way, a SNS learning environment provides various opportunities for students and teachers alike to interact and learn from each other. In a recent study, Davies (2011) focuses on 25 British teenagers' language and literacy practices on Facebook. Results have shown that Facebook do function as a new medium of self-presenting and making friends. In sum, SNS learning communities can effectively function as a learning tool. However, educators must guide their students and model effective knowledge construction and collaboration by establishing trusting relationships with students through appropriate feedback and adequate supervision (Kok, 2008).

\subsection{Personality traits}

Defining personality is quite a complex task. In general, the word personality is derived from the Latin word persona; which means mask (Burger, 1993). More specifically, the word personality conveys a sense of consistency, internal causality, and personal distinctiveness (Carver \& Scheier, 2000, p. 5). Hence, it can be said that the study of personality can be understood as the study of unique masks that people wear. Personality can also be defined as the complex of characteristics that distinguishes an individual from one another; sometimes also referred to as the totality of an individual's behavioral and emotional characteristics (Personality, 2012). In the late 1930s, Allport and Odbert (1936) mentioned that personality is everything that makes someone an individual. More importantly, they also mentioned the various traits that exist within the personality of an individual.

A trait is a consistent psychological, behavioral, or physical characteristic such as shyness, level of physical activity, or even the shape of a nose or ear (Allport \& Odbert, 1936). Traits is also considered as the consistent patterns of thoughts, feelings, or actions that distinguish people from one another (Pervin \& John, 1999). In other words, traits are like the profiles of each person. No two people are exactly the same; not even identical twins. Some people are careful, and some are careless, while some are arrogant and some are shy. This issue of differences is fundamental to the study of personality. Such as in profiling an individual, who requires that people be rated or described using a series of traits or dimensions. In essence, an individual's personality would be seen as an integration or configuration of these different traits or dimensions (Allport \& Odbert, 1936).

\subsection{Big Five personality trait}

It is said that the basis tendencies in personality traits remains stable across the life span, but characteristic behavior can change considerably through adaptive processes (Caspi, Roberts, \& Shiner, 2005; Hogan, Johnson, 
\& Briggs, 1997; Potkay \& Allen, 1986). A trait is an internal characteristic that corresponds to an extreme position on a behavioral dimension (Guildford, 1959). Although there are many different theoretical perspectives in the field of personality psychology the labels Big Five and Five Factor Model (FFM) are often used interchangeably when considering the trait approach to personality theory.

Big Five personality trait is derived from numerous studies such as the seminal works of Allport and Odbert (1936), Fiske (1949), Tupes and Christal (1961), and Norman (1963), and the more recent studies by Goldberg (1993) and McCrae and Costa (1996, 2003). The Big Five personality represents a kind of classification system of traits that some psychologists suggest capture the essence of individual differences in personality. The Big Five personality trait is composed of the following (with their corresponding opposing traits) (Hogan \& Hogan, 1992; Hogan et al., 1997; Pervin \& John, 1999; Potkay \& Allen, 1986):

a. Extraversion (introversion): denotes a person who is talkative, social, and assertive;

b. Agreeableness (antagonism): denotes a person who is of good natured, co-operative, and trusting;

c. Conscientiousness (un-directedness): denotes a person who is responsible, orderly, and dependable;

d. Neuroticism (emotional stability): denotes a person who is anxious, prone to depression, and worries a lot; and

e. Openness to experience (not open to experience): denotes a person who is imaginative, independent minded, and has divergent thinking.

The Big Five personality structure is a major improvement over other earlier personality factor systems that tended to compete with each other, rather than establish commonalities and convergences. McCrae and Costa (1996, 2003) further explains the following Big Five concepts as:

a. Extraversion implies an energetic approach to the social and material world and includes traits such as sociability, activity, assertiveness, and positive emotionality;

b. Agreeableness contrasts a pro-social and communal orientation toward others with antagonism and includes traits such as altruism, tender-mindedness, trust, and modesty;

c. Conscientiousness describes socially prescribed impulse control that facilitates task and goal-directed behavior, such as thinking before acting, delaying gratification, following norms and rules, and planning, organizing, and prioritizing tasks;

d. Neuroticism contrasts emotional stability and even-temperedness with negative emotionality, such as feeling anxious, nervous, sad, and tense; and

e. Openness to experience (versus closed-mindedness) describes the breadth, depth, originality, and complexity of an individual's mental and experiential life.

In essence, the Big Five personality structure captures, at a broad level of abstraction, the commonalities among most of the existing systems of personality description, and provides an integrative descriptive model for personality research (John \& Srivastava, 1999, p. 131).

\subsection{Previous related studies with regards to personality and Facebook habits}

Various studies have mentioned that there are indeed significant relationships among a person's personality and their Facebook usage habits. In a very recent study, researchers have point out that people uses Facebook mainly for the following reasons: 1) the need to belong, and (2) the need for self-presentation (Nadkarni \& Hofmann, 2012) and self-esteem (Abellera, Ouano, Conway, Camilotes, \& Doctor, 2012). In addition, studies have shown that Facebook usage is quite related to a persons' state of depression (J. A. Datu, Valdez, \& Datu, 
2012). From their summary of 78 studies involving Facebook usage, the researchers further added that Facebook usage is much related to an individual's tendency in neuroticism, narcissism, shyness, self-esteem, and self-worth.

In another study done in Malaysia, findings show that unethical online behaviors are much related to time-spent online. Of the 252 university students surveyed, strong negative relationship is found on the personalities such as Agreeableness, Conscientiousness, and Neuroticism (emotional stability) with unethical internet behaviors (Karim, Zamzuri, \& Nor, 2009). More importantly, this study suggests that school should look into their internet usage policy and enhance their online ethics education, so as to familiarize their students with the right usage of technology.

One typical study mentioned that the relationship of Facebook usage and a person's personality is not that significant, however, the personality Openness is definitely related to a person's online sociability (tendency of making friends online) (Ross et al., 2009). While, Facebook is becoming more famous day by day; Facebook usage is still pretty much governed by a person's need to communicate with others. Hence, this study suggest that Facebook friends is the result of previous meeting (engagement) with new friends either offline or online (other SNS besides Facebook).

Within an educational setting, Hew (2011) compiled a series of studies regarding in-school Facebook usages. After analyzing 539 studies, findings suggest that overall Facebook usage to be of very little educational use. Students tend to mainly keep in touch with their friends. Although expected, students do disclose more personal information about themselves on Facebook. Hence, proper guidance must be given in order to avoid improper dissemination of personal information.

In a study consisting of 1324 Australian internet users; results suggest that Facebook users tend to be more extraverted and narcissistic, but less conscientious (Ryan \& Xenos, 2011). Similar to previous studies, Australian Facebook users tends to be more socially lonely than non-users. Lastly, a recent study mentioned that the different ways Facebook users set their profiles whether public or private relies on tendencies to exercise greater degree of self-control, order and regulation (N. D. Datu, Datu, \& Rungduin, 2013). Hence, it is said that Facebook profile settings can be influenced by innate predispositions in the form of personality traits.

In sum, numerous studies have depicted the relationship of personality and Facebook usage habits. Many studies have stated various significant correlations among the traits and perceived satisfaction of Facebook use, more specifically a person's sense of social community. With the varied perspective on Facebook habits, the current study shall try to pin-point in contrast further findings on Facebook habits with college students in Taiwan.

\section{Research Methodology}

\subsection{Research design}

This research is designed as a case study, wherein the primary objective is to investigate a contemporary phenomenon within its real-life context; when the boundaries between phenomenon and context are not clearly evident; and in which multiple sources of evidence are used (Yin, 1984, p. 23). Furthermore, Merriam (1998) views a case as an individual, a program, a class or students, a school, or a community. She fashions the distinctiveness of case studies as particularistic because of the focus on one social unit; descriptive because they result in a rich thick portrait; and heuristic because case studies sharpen readers' understanding while leading to a new meanings.

Furthermore, this study is also designed as a descriptive research paradigm; a qualitative research that is concerned with how something that exists is related to some preceding event that has influenced or affected a present condition or event. Descriptive research, according to Best (1970) is concerned with conditions or 
Wang, C. Y. \& Ching, G. S.

relationships that exist, practices that prevail, beliefs, points of views, or attributes that are held, processes that are ongoing, effects that are being felt; or developing trends.

\subsection{Participants and research process}

A total of 132 volunteer EFL students of a science and technology university in Taiwan participated in the study. Students are all from the Applied Foreign Language (AFL) department. Among the participants there are 103 or $78 \%$ female students and 29 or $22 \%$ male students. Their average age is around 27 years old. The high average age is due to the diverse nature of participants. Within the 132 participants, there are 35 or $26.50 \%$ freshmen ( $1^{\text {st }}$ year), 53 or $40.20 \%$ junior $\left(3^{\text {rd }}\right.$ year $)$, and 44 or $33.30 \%$ senior $\left(4^{\text {th }}\right.$ year $)$ students.

With regards to the students study program, the participants are composed of 59 or $44.70 \%$ from the morning (regular classes) session, 23 or $17.40 \%$ from the evening session, and 50 or $37.90 \%$ from the weekend (extension education) session. In addition, 92 or $69.70 \%$ of the participants are already working, while only 13 or $9.80 \%$ are living in the campus dorm.

\section{Table 1}

Participants' demography (N=132)

\begin{tabular}{|c|c|c|c|c|}
\hline Items & $n$ & $\%$ & Mean & $S D$ \\
\hline Age/Gender & & & 27.22 & 9.20 \\
\hline Female & 103 & 78.00 & 26.17 & 8.71 \\
\hline Male & 29 & 22.00 & 30.93 & 10.58 \\
\hline \multicolumn{5}{|l|}{ Level } \\
\hline Freshmen & 35 & 26.50 & & \\
\hline Junior & 53 & 40.20 & & \\
\hline Senior & 44 & 33.30 & & \\
\hline \multicolumn{5}{|l|}{ Type } \\
\hline Morning & 59 & 44.70 & & \\
\hline Evening & 23 & 17.40 & & \\
\hline Weekend & 50 & 37.90 & & \\
\hline \multicolumn{5}{|c|}{ Employed (working) } \\
\hline Yes & 92 & 69.70 & & \\
\hline No & 40 & 30.30 & & \\
\hline \multicolumn{5}{|c|}{ Living in school dorm } \\
\hline Yes & 13 & 9.80 & & \\
\hline No & 119 & 90.20 & & \\
\hline
\end{tabular}

The current study was accomplished during the 2011 to 2012 school year. After the literature review and formation of the survey questionnaire, the survey was administered to 150 students with an effective return of 132 participants. For the survey validity, the overall Cronbach Alpha reliability is computed to be at 0.793, which is considered quite highly reliable (Cohen, Manion, \& Morrison, 2007).

\subsection{The Big Five Inventory (BFI)}

There has been quite a few inventory developed just to measure the Big Five personality traits (John \& Srivastava, 1999). Such as the Goldberg (1992) 50 items inventory called transparent format, which uses a set of 100 uni-polar trait descriptive adjectives or TDA (Goldberg, 1990). Similarly, Hogan and Hogan (1992) developed the 206 items Hogan Personality Inventory (HPI), which originated from a 225 items (310 items if counting the 85 un-scored items) inventory.

Another well-known tool is the 240 items NEO Personality Inventory or more commonly known as the 
NEO PI-R developed by Costa \& McCrae (1992), which was later shorten into another version called the 60 items NEO-Five Factor Inventory (NEO-FFI). Currently, the inventories have undergone several updates in order to accommodate and better capture the essence of the personality traits being measure (McCrae \& Costa, 2010; McCrae, Costa, \& Martin, 2005).

Another highly used tool is John et al. (1991) 44 items Big Five Inventory (BFI). The main features of the BFI are its short phrased items. The BFI does not use single adjectives as items, because such items are answered less consistently than when they are accompanied by definitions or elaborations; instead the BFI uses short phrases (Goldberg \& Kilkowski, 1985). The goal of BFI is to create a brief inventory that would allow efficient and flexible assessment of the five personality traits (John \& Srivastava, 1999; Rammstedt \& John, 2007). Furthermore, shorter inventories do not only saves time, but also avoid participants boredom and fatigue while taking the test (Burisch, 1984, p. 219). Hence, the BFI items retain the advantages of adjectival items (brevity and simplicity) while avoiding some of their pitfalls (ambiguous or multiple meanings and salient desirability) (John \& Srivastava, 1999, p. 115).

Although the BFI scales include only eight to ten items for each of the personality traits, BFI do not sacrifice either content coverage or good psychometric properties (John \& Srivastava, 1999). BFI is also said to be reliable in measuring the five personality traits across diverse human cultures (Rammstedt \& John, 2007; Schmitt, Allik, McCrae, \& Benet-Martínez, 2007). Furthermore, BFI can be used in studies regarding various fields such as students' in-school (in-class) behaviors, cross-cultural issues, person and organization issues, and many others (McCrae \& John, 1992; Potkay \& Allen, 1986).

In most of the cases, the Cronbach Alphas $(\alpha)$ (1951) reliabilities of the studies that uses the BFI scales typically range from 0.75 to 0.90 with an average of above 0.80 (John \& Srivastava, 1999). As a rule $\alpha$ should be greater than 0.45 , hence, an $\alpha$ greater than 0.80 denotes high reliability (Carmines \& Zeller, 1991; Nunnally, 1970). In essence, BFI is a highly reliable tool that can be effectively used to measure an individuals' personality in terms of the five major traits.

\subsection{Data analysis}

Quantitative statistical analyses such as the mean and percentage, and correlation reports between the various personality traits and Facebook usage habits of the students were computed by means of the statistical software Statistics Package for Social Scientist (SPSS).

\section{Results and discussions}

This study is focus on understanding the students' Facebook usage habits in a science and technology university in Taiwan. Using the Big Five Personality Inventory, the study aims to look into the how and why students are geared towards certain Facebook usage habits. Results are separated into three sections: 1) The common Facebook usage habits of the students; 2) Factors that influence the students' Facebook usage habits; and 3) The relationship between the students' personality and their Facebook usage habits.

\subsection{The common Facebook usage habits of the students}

The data collected from the 132 participants is analyzed using the statistical software SPSS. With regards to the participants' Facebook usage habits, results show that on average, students open their Facebook page almost three times a day. This is confirmed by the responds from 60 or $46 \%$ of the students stating that they tend to use their Facebook account at least once or twice a day. One interesting finding is the notion of the time-spent on Facebook usage per day with an average of only three minutes.

Table 2 also shows that almost everyone has a Facebook account and around 82\% of 132 stated that they only have one single account. However, 17 or almost $13 \%$ mentioned that they have two Facebook accounts. To 
Wang, C. Y. \& Ching, G. S.

what purpose of having more than one Facebook account would be a good follow up study. Data also shows that most of the participants already have a Facebook account before going to college with 84 or almost $64 \%$ of the respondents.

Table 2

Participants' Facebook details (N=132)

\begin{tabular}{|c|c|c|c|c|c|c|}
\hline Items & $n$ & $\%$ & Minimum & Maximum & Mean & $S D$ \\
\hline \multicolumn{7}{|l|}{ Do you have a FB account? } \\
\hline Yes & 130 & 98.50 & & & & \\
\hline No & 2 & 1.50 & & & & \\
\hline Number of FB accounts & & & 0 & 3 & 1.17 & 0.50 \\
\hline 0 & 3 & 2.30 & & & & \\
\hline 1 & 108 & 81.80 & & & & \\
\hline 2 & 17 & 12.90 & & & & \\
\hline 3 & 4 & 3.00 & & & & \\
\hline Number of times opening FB & & & 1 & 6 & 2.80 & 1.23 \\
\hline Once/twice a week & 7 & 5.30 & & & & \\
\hline 1 to 2 times a day & 60 & 45.50 & & & & \\
\hline 3 to 5 times a day & 41 & 31.10 & & & & \\
\hline 6 to 10 times a day & 10 & 7.60 & & & & \\
\hline 11 to 15 times a day & 4 & 3.00 & & & & \\
\hline 16 or more times a day & 10 & 7.60 & & & & \\
\hline Times spent on FB (per day) & & & 1 & 7 & 3.85 & 1.61 \\
\hline Never & 2 & 1.50 & & & & \\
\hline Not sure & 4 & 3.00 & & & & \\
\hline Less than 15 minutes & 34 & 25.80 & & & & \\
\hline 15 to 30 minutes & 31 & 23.50 & & & & \\
\hline 31 to 45 minutes & 13 & 9.80 & & & & \\
\hline 1 hour & 23 & 17.40 & & & & \\
\hline 2 hours or more & 25 & 18.90 & & & & \\
\hline Started using FB & & & 0.00 & 3.00 & 1.48 & 0.77 \\
\hline No FB account & 2 & 1.50 & & & & \\
\hline Before college & 84 & 63.60 & & & & \\
\hline 1 st year of college & 26 & 19.70 & & & & \\
\hline After 1st year of college & 20 & 15.20 & & & & \\
\hline Number of friends & & & 0 & 2046 & 257.97 & 260.59 \\
\hline Having unknown FB friends & & & 1 & 5 & 3.23 & 1.52 \\
\hline Number of FB community & & & 0 & 30 & 6.53 & 5.59 \\
\hline
\end{tabular}

Note . $n$ in bold = most number of selections.

With regards to the number of friends, it is quite interesting to find out that on average, each Facebook account has around 258 friends with the maximum number of friends amounting to 2046. While an average of 6 communities are found on each of the Facebook accounts. These results suggest that the participants are quite socially active in their Facebook usage. In order to further analyze the background demography of the participants, the Big Five Personality Inventory is used to gather the participants' characteristics and traits. Table 3 summarizes the results of the personality analysis. Result suggests that most AFL students are quite inclined to the trait Openness. This means that AFL students are willing to try on new experiences.

Further analysis of the data suggests that female participants scored higher in the personality Extroversion 
A study on the relationship of Facebook and EFL learners' personality

and Neuroticism; suggesting that they are both more sociable and emotional than their male counterparts. For the male participants, they scored higher in the personality traits Agreeableness, Conscientiousness, and Openness. With respect to the students program of study, regular class (morning session) students tend to be more emotional than the rest of the participants. While, the evening session students shows much potential in their personalities Extroversion, Agreeableness, Conscientiousness, and Openness.

Table 3

Participants' Big Five Personality scores $(N=132)$

\begin{tabular}{lrrrl}
\hline \multicolumn{1}{c}{ Personality } & Minimum & Maximum & Mean & $S D$ \\
\hline Extroversion & 3 & 36 & 21.88 & 5.90 \\
Agreeableness & 10 & 40 & 26.12 & 4.75 \\
Conscientiousness & 1 & 39 & 23.04 & 5.60 \\
Neuroticism & 0 & 33 & 18.47 & 5.39 \\
Openness & 4 & 45 & $\mathbf{2 7 . 0 5}$ & 7.19 \\
\hline
\end{tabular}

Table 4

Participants' demography and their Big Five Personality scores $(N=132)$

\begin{tabular}{|c|c|c|c|c|}
\hline Items & Minimum & Maximum & Mean & $S D$ \\
\hline \multicolumn{5}{|l|}{ Female $(n=103)$} \\
\hline Extroversion & 10 & 36 & 24.02 & 5.02 \\
\hline Agreeableness & 14 & 40 & 27.61 & 4.48 \\
\hline Conscientiousness & 1 & 39 & 25.27 & 5.26 \\
\hline Neuroticism & 5 & 33 & 20.50 & 4.91 \\
\hline Openness & 15 & 45 & 29.55 & 5.93 \\
\hline \multicolumn{5}{|l|}{ Male $(n=29)$} \\
\hline Extroversion & 17 & 31 & 23.83 & 3.93 \\
\hline Agreeableness & 18 & 36 & 27.83 & 3.87 \\
\hline Conscientiousness & 19 & 34 & 26.72 & 3.77 \\
\hline Neuroticism & 12 & 29 & 19.83 & 3.50 \\
\hline Openness & 21 & 41 & 30.76 & 5.59 \\
\hline \multicolumn{5}{|c|}{ Regular morning session students $(n=59)$} \\
\hline Extroversion & 10 & 36 & 23.66 & 5.15 \\
\hline Agreeableness & 14 & 40 & 27.53 & 4.94 \\
\hline Conscientiousness & 15 & 37 & 24.75 & 4.34 \\
\hline Neuroticism & 12 & 32 & 22.08 & 4.41 \\
\hline Openness & 15 & 44 & 29.59 & 6.09 \\
\hline \multicolumn{5}{|c|}{ Evening session students $(\mathrm{n}=23)$} \\
\hline Extroversion & 20 & 33 & 25.35 & 4.47 \\
\hline Agreeableness & 21 & 39 & 28.52 & 4.22 \\
\hline Conscientiousness & 1 & 39 & 26.30 & 7.46 \\
\hline Neuroticism & 5 & 27 & 17.83 & 5.01 \\
\hline Openness & 24 & 45 & 30.52 & 5.54 \\
\hline \multicolumn{5}{|c|}{ Weekend session students $(\mathrm{n}=50)$} \\
\hline Extroversion & 15 & 34 & 23.72 & 4.45 \\
\hline Agreeableness & 17 & 35 & 27.42 & 3.61 \\
\hline Conscientiousness & 17 & 39 & 26.26 & 4.22 \\
\hline Neuroticism & 12 & 33 & 19.46 & 3.96 \\
\hline Openness & 18 & 43 & 29.76 & 5.81 \\
\hline
\end{tabular}


Wang, C. Y. \& Ching, G. S.

\section{Table 5}

Participants' year level and their Big Five Personality scores $(N=132)$

\begin{tabular}{lcccc}
\hline \multicolumn{1}{c}{ Items } & Minimum & Maximum & Mean & $S D$ \\
\hline Freshmen (n=35) & & & & \\
Extroversion & 15 & 35 & 23.54 & 4.54 \\
Agreeableness & 18 & 40 & 24.66 & 4.41 \\
Conscientiousness & 15 & 33 & $\mathbf{2 1 . 6 6 ^ { 1 }}$ & 4.25 \\
Neuroticism & 12 & 30 & 29.37 & 6.19 \\
Openness & 16 & 44 & & 5.08 \\
\hline Junior (n=53) & & & 23.04 & 4.70 \\
Extroversion & 10 & 36 & 27.17 & 4.77 \\
Agreeableness & 14 & 38 & 25.70 & 4.59 \\
Conscientiousness & 18 & 39 & 21.15 & 6.49 \\
Neuroticism & 13 & 33 & 29.25 & 4.33 \\
Openness & 15 & 43 & & 3.82 \\
Senior (n=44) & & & $\mathbf{2 5 . 4 5}$ & 5.83 \\
Extroversion & 15 & 34 & $\mathbf{2 8 . 2 5}$ & 4.38 \\
Agreeableness & 17 & 39 & $\mathbf{2 6 . 3 2}$ & 4.66 \\
Conscientiousness & 1 & 39 & 18.34 & $\mathbf{3 0 . 8 6}^{1}$ \\
Neuroticism & 5 & 27 & & \\
Openness & 24 & 45 & & \\
\hline
\end{tabular}

Note. ${ }^{1}$ Highest mean score.

With respect to year level, $1^{\text {st }}$ year students scored highest in the personality Neuroticism, while the senior students scored highest on the rest of the different personality traits. These results suggest that personality is somewhat related to a persons' age. Further analysis in the following sections shall provide an even deeper explanation among the correlations of the career dimensions and personality. (Please see table 5 for more details)

\subsection{Factors that influence the students' Facebook usage habits}

To further understand the influence of Facebook usage habits, various questions regarding the reason why participants uses Facebook are asked. Table 6 and 7 shows the summary of the results.

Table 6

Purpose in using Facebook $(N=132)$

\begin{tabular}{llc}
\hline \multicolumn{1}{c}{ Items } & $n$ & $\%$ \\
\hline Use FB to send message & 97 & $73 \%$ \\
Use FB to keep up with what is happening & 88 & $67 \%$ \\
Use FB for chatting with friends & 83 & $63 \%$ \\
Use FB to share my information & 71 & $54 \%$ \\
Use FB for to lookup (re-connect) with old friends & 52 & $39 \%$ \\
Use FB for making friends & 46 & $35 \%$ \\
Use FB for express my online status & 46 & $35 \%$ \\
Use FB for common interest group & 38 & $29 \%$ \\
Use FB for playing games & 36 & $27 \%$ \\
Use FB for work group & 36 & $27 \%$ \\
\hline
\end{tabular}

With regards to Facebook usage habits, participants rank highest the "Use FB to send message" with 97 or $73 \%$, while "Use FB for work group" as the lowest with 36 or 27\%. Such results imply that in-school (or 
curriculum related) Facebook usage is not that feasible. Further findings show that "Use FB to keep up with what is happening" with 88 or $67 \%$ and "Use FB for chatting with friends" with 83 or $63 \%$ are also quite high. These actually create the concern for email usage; wherein students rely much on Facebook to communicate with others than opening (checking) their emails accounts. (Please see table 6 for more details)

As for the implications of using Facebook, table 7 shows a summary of the results from the 132 participants. Almost all of the participants allow their friends to view their Facebook page with 128 or 97\%, although recognizing that Facebook is not safe and having no privacy at all with 123 or $93 \%$. Students tend to recommend Facebook use with 86 or $65 \%$, while the notion of plagiarism is quite high with 70 or $53 \%$. In sum, implications from their Facebook usage purposes and limitations suggest that participants are quite knowledgeable regarding the functions and consequences of Facebook. (Please see table 7 for more details)

Table 7

Opinions on using Facebook $(N=132)$

\begin{tabular}{lcc}
\hline \multicolumn{1}{c}{ Items } & $n$ & $\%$ \\
\hline Friends can view my FB & 128 & $97 \%$ \\
There is no privacy in FB & 123 & $93 \%$ \\
Classmates can view my FB & 110 & $83 \%$ \\
My FB have more contacts than my email & 105 & $80 \%$ \\
True pictures in FB profile & 104 & $79 \%$ \\
Uses POKE function on FB & 87 & $66 \%$ \\
Everybody should use FB & 86 & $65 \%$ \\
Family can view my FB & 85 & $64 \%$ \\
FB is a waste of time & 74 & $56 \%$ \\
Free to use information in FB as I please & 70 & $53 \%$ \\
I can say whatever I want in FB & 69 & $52 \%$ \\
Teacher can view my FB & 67 & $51 \%$ \\
Restrict view on my FB & 60 & $45 \%$ \\
After having FB I use less email & 51 & $39 \%$ \\
Using FB is safe & 22 & $17 \%$ \\
Anyone can view FB & 16 & $12 \%$ \\
\hline
\end{tabular}

Further analysis on the other demographical factors that influences Facebook use is accomplished. The independent sample T-test was used to determine if there are any differences between the participants' gender, whether they are working, and whether they lived in the school dorm. Findings show that there are no significant differences between the participants' gender and their personality; as with their Facebook details. However, the independent sample T-test results also show that there exists a significant difference in the personality factor Extroversion for students' who are either working $(\mathrm{M}=24.72, \mathrm{SD}=4.81)$ or not $(\mathrm{M}=22.28, \mathrm{SD}=4.33)$ with $\mathrm{t}(130)=2.76, p=0.007$.

Furthermore, significant difference is also found on the participants' number of times opening Facebook per day for students' who are either working $(\mathrm{M}=3.78, \mathrm{SD}=1.66)$ or not $(\mathrm{M}=4.00, \mathrm{SD}=1.50)$ with $\mathrm{t}(130)=2.27$, $p=0.025$. Lastly, significant difference is also found on the participants' number of Facebook community for students' who are either working $(\mathrm{M}=5.80, \mathrm{SD}=5.57)$ or not $(\mathrm{M}=8.20, \mathrm{SD}=5.34)$ with $\mathrm{t}(130)=2.30, p=0.023$. (Please see table 8 for more details)

With respect to the relationship between student year levels and personality traits, analysis of variance (ANOVA) results show that there exist significant differences among the various year levels for the trait Extraversion with $\mathrm{F}(3,129)=3.38$, $p<0.037$, further analysis shows that Junior $(\mathrm{M}=23.04)$ students scored significantly lower than the Senior $(M=25.45)$ students. In addition, there also exist significant differences 
Wang, C. Y. \& Ching, G. S.

among the various year levels for the trait Neuroticism with $\mathrm{F}(3,129)=6.90, p<0.001$, further analysis shows that Senior $(M=18.34)$ students scored significantly lower than that of the Freshmen $(M=21.66)$ and Juniors $(\mathrm{M}=21.15)$ students.

Table 8

$T$-test results on the differences in participants' Big Five Personality and FB details $(N=132)$

\begin{tabular}{llccccc}
\hline \multicolumn{1}{c}{ Items } & & \multicolumn{7}{c}{ Work } & & & eta \\
\hline Extraversion & Mean & 24.72 & 22.28 & $\mathbf{2 . 7 6}$ & 0.007 & 0.055 \\
& $S D$ & 4.81 & 4.33 & & & \\
Agreeableness & Mean & 28.01 & 26.85 & 1.42 & 0.159 & 0.015 \\
& $S D$ & 4.08 & 4.84 & & & \\
Conscientiousness & Mean & 25.85 & 25.00 & 0.90 & 0.372 & 0.006 \\
& $S D$ & 5.24 & 4.37 & & & \\
Neuroticism & Mean & 20.00 & 21.15 & 1.32 & 0.191 & 0.013 \\
& $S D$ & 4.56 & 4.76 & & & \\
Openness & Mean & 30.15 & 29.05 & 0.99 & 0.322 & 0.007 \\
& $S D$ & 5.58 & 6.47 & & & \\
\hline Number of times opening FB & Mean & 2.93 & 2.50 & $\mathbf{2 . 2 7}$ & 0.025 & 0.038 \\
& $S D$ & 1.36 & 0.82 & & & \\
Number of FB community & Mean & 5.80 & 8.20 & $\mathbf{2 . 3 0}$ & 0.023 & 0.039 \\
& $S D$ & 5.57 & 5.34 & & & \\
\hline
\end{tabular}

Note. $t$ in bold $=$ significant differences in values. $d f=130$.

With regards to the participants' Facebook usage habits, ANOVA results show that there exist a significant differences among the various year levels for the time-spent on Facebook with $\mathrm{F}(3,129)=7.94, p<0.001$. In-depth analysis shows that Senior (M=3.16) students spent significantly less time than the freshmen $(M=3.98)$ and junior $(\mathrm{M}=4.51)$ students. Similarly, there exists a significant differences between the various school years with the number of member communities with $\mathrm{F}(3,129)=14.56, p<0.000$, number of friends with $\mathrm{F}(3,129)=6.27$, $p<0.003$, and year started using Facebook with $\mathrm{F}(3,129)=10.51, p<0.000$.

Furthermore, with regards to the students' study sessions; ANOVA results show that there exist significant differences for the personality trait Neuroticism with F(3,129)=9.60, $p<0.000$ in students of different study sessions. While for the Facebook usage habits, ANOVA results show that there are significant differences for time-spent using Facebook with $\mathrm{F}(3,129)=9.39, \quad p<0.000$, number of member communities with $\mathrm{F}(3,129)=45.920, p<0.000$, and number of friends with $\mathrm{F}(3,129)=7.15, p<0.001$ in students of different study sessions.

\subsection{The relationship between the students' personality and their Facebook usage habits}

To determine the various relationships among the students' personality and their Facebook usage habits, correlation analysis was accomplished using the statistical software SPSS. Table 9 shows the various correlations among the factors (variables). Values highlighted in bold shows that there is a statistical significant correlation among the two factors (above and across).

Results show that the time spent on Facebook is positively correlated with Neuroticism with 0.343 $(p<0.000)$. This suggests that when the value for time spent on Facebook increases, Neuroticism increases. This also means that the more time the participants' spent time on Facebook, the more emotional they are.

In addition, correlation results also show that having unknown Facebook friends is negatively correlated to 
A study on the relationship of Facebook and EFL learners' personality

Conscientiousness with $0.194(p<0.025)$. This suggests that AFL students quite careful in adding new friends. However, less conscious participants tend to have a high number of friends.

\section{Table 9}

Correlations among the variables $(N=132)$

\begin{tabular}{|c|c|c|c|c|c|c|c|c|c|c|c|c|}
\hline & Items & & 1 & 2 & 3 & 4 & 5 & 6 & 7 & 8 & 9 & 10 \\
\hline \multirow[t]{2}{*}{ (1) } & Extraversion & $r$ & & & & & & & & & & \\
\hline & & $p$ & & & & & & & & & & \\
\hline \multirow[t]{2}{*}{ (2) } & Agreeableness & $r$ & 0.384 & & & & & & & & & \\
\hline & & $p$ & 0.000 & & & & & & & & & \\
\hline \multirow[t]{2}{*}{ (3) } & Conscientiousness & $r$ & 0.385 & 0.367 & & & & & & & & \\
\hline & & $p$ & 0.000 & 0.000 & & & & & & & & \\
\hline \multirow[t]{2}{*}{ (4) } & Neuroticism & $r$ & -0.324 & -0.135 & -0.447 & & & & & & & \\
\hline & & $p$ & 0.000 & 0.124 & 0.000 & & & & & & & \\
\hline \multirow[t]{2}{*}{ (5) } & Openness & $r$ & 0.379 & 0.343 & 0.258 & -0.194 & & & & & & \\
\hline & & $p$ & 0.000 & 0.000 & 0.003 & 0.026 & & & & & & \\
\hline \multirow[t]{2}{*}{ (4) } & Number of FB accounts & $r$ & -0.059 & -0.019 & 0.055 & -0.075 & 0.050 & & & & & \\
\hline & & $p$ & 0.499 & 0.825 & 0.528 & 0.391 & 0.570 & & & & & \\
\hline (7) & Number of times opening & $r$ & 0.046 & -0.061 & -0.110 & 0.131 & -0.050 & 0.366 & & & & \\
\hline FB & & $p$ & 0.602 & 0.486 & 0.209 & 0.134 & 0.566 & 0.000 & & & & \\
\hline \multirow[t]{2}{*}{ (8) } & Times spent on FB & $r$ & 0.004 & -0.037 & -0.159 & 0.343 & 0.022 & 0.127 & 0.392 & & & \\
\hline & & $p$ & 0.959 & 0.675 & 0.069 & 0.000 & 0.801 & 0.147 & 0.000 & & & \\
\hline \multirow[t]{2}{*}{ (9) } & Started using FB & $r$ & -0.014 & -0.099 & -0.010 & 0.045 & -0.043 & -0.013 & -0.149 & -0.181 & & \\
\hline & & $p$ & 0.877 & 0.258 & 0.913 & 0.612 & 0.624 & 0.879 & 0.089 & 0.038 & & \\
\hline \multirow[t]{2}{*}{ (10) } & Number of friends & $r$ & 0.130 & 0.030 & -0.062 & 0.165 & 0.079 & 0.093 & 0.241 & 0.447 & -0.131 & \\
\hline & & $p$ & 0.139 & 0.733 & 0.477 & 0.059 & 0.368 & 0.288 & 0.005 & 0.000 & 0.134 & \\
\hline \multirow[t]{2}{*}{ (11) } & Having unknown FB friends & $r$ & 0.139 & 0.093 & -0.194 & 0.168 & -0.045 & 0.091 & 0.192 & 0.267 & -0.043 & 0.404 \\
\hline & & $p$ & 0.113 & 0.288 & 0.025 & 0.054 & 0.607 & 0.298 & 0.028 & 0.002 & 0.625 & 0.000 \\
\hline \multirow[t]{2}{*}{ (12) } & Number of FB community & $r$ & 0.030 & 0.020 & -0.102 & 0.213 & 0.089 & 0.171 & 0.335 & 0.451 & -0.052 & 0.403 \\
\hline & & $p$ & 0.737 & 0.822 & 0.243 & 0.014 & 0.311 & 0.050 & 0.000 & 0.000 & 0.557 & 0.000 \\
\hline \multirow[t]{2}{*}{ (13) } & Student type & $r$ & 0.010 & -0.008 & 0.140 & -0.266 & 0.015 & 0.059 & -0.073 & -0.298 & -0.095 & -0.238 \\
\hline & & $p$ & 0.908 & 0.929 & 0.109 & 0.002 & 0.866 & 0.501 & 0.403 & 0.001 & 0.281 & 0.006 \\
\hline \multirow[t]{2}{*}{ (14) } & Year level & $r$ & 0.130 & 0.039 & 0.141 & -0.254 & 0.086 & 0.057 & -0.112 & -0.312 & 0.295 & -0.294 \\
\hline & & $p$ & 0.137 & 0.654 & 0.108 & 0.003 & 0.326 & 0.516 & 0.201 & 0.000 & 0.001 & 0.001 \\
\hline
\end{tabular}

Note. $r$ in bold = significant correlations among the variables.

\section{Conclusions}

The current study exemplifies the use of the Big Five Personality scale to understand EFL students' Facebook habits. This case study, though limited to the sample coming from a science and technology university, shows that AFL students are more quite conscious in having an online lifestyle. As shown in the results that the 
frequency for time-spent is quite moderate. Furthermore, students who are more Conscientious tends to avoid having unknown Facebook friends. However, this on the other spectrum means that students who are not careful tend to have many friends. In sum, individuals' Facebook habits are much related to an individual's background demographics. Hence, in order to have a healthy online lifestyle, it is recommended that students should know the consequences of both good and bad Facebook habits.

Acknowledgement: The study was supported by funding from the National Science Council, Taiwan (Project No. NSC 101-2410-H-262-011). I am grateful to the anonymous reviewers for the valuable comments and suggestions.

\section{References}

Abellera, N. A. C., Ouano, J. A., Conway, G. D., Camilotes, L. M. C., \& Doctor, H. M. L. (2012). The mediating effect of relatedness on Facebook use and self-esteem. International Journal of Research Studies in Psychology, 1(3), 59-67. http://dx.doi.org/10.5861/ijrsp.2012.298

Allport, G. W., \& Odbert, H. S. (1936). Trait-names: A psycho-lexical study. Psychological Monographs, 47, 1-211. http://dx.doi.org/10.1037/h0093360

Best, J. W. (1970). Research in education. Englewood Cliffs, NJ: Prentice Hall.

Blattner, G., \& Fiori, M. (2011). Virtual social network communities: An investigation of language learners' development of sociopragmatic awareness and multiliteracy skills. CALICO, 29(1), 24-43.

Burger, J. M. (1993). Personality (3rd ed.). Pacific Grove, CA: Brooks/Cole.

Burisch, M. (1984). Approaches to personality inventory construction. American Psychologist, 39, 214-227. http://dx.doi.org/10.1037/0003-066X.39.3.214

Carmines, E. G., \& Zeller, R. A. (1991). Reliability and viability assessment. Thousand Oaks, CA: Sage.

Carver, C. S., \& Scheier, M. F. (2000). Perspectives on personality (4th ed.). Boston: Allyn and Bacon.

Caspi, A., Roberts, B., \& Shiner, R. L. (2005). Personality development: Stability and change. Annual Review of Psychology, 56, 453-484. http://dx.doi.org/10.1146/annurev.psych.55.090902.141913

Chang, B., Cheng, N. H., Deng, Y. C., \& Chan, T. W. (2007). Environmental design for a structured network learning society. Computers \& Education, 48(2), 234-249. http://dx.doi.org/10.1016/j.compedu.2004.11.008

Chen, F. C., \& Wang, T. (2009). Social conversation and effective discussion in online group learning. Educational Technology Research and Development, 57(5), 587-612. http://dx.doi.org/10.1007/s11423-009-9121-1

China Times. (2011). An increased in Facebook usage of 27\%: A major different from last year's findings [In Chinese]. Retrieved December 25, 2011, from http://blog.chinatimes.com/yenhao2010/archive/2011/09/26/964658.html

Cohen, L., Manion, L., \& Morrison, K. (2007). Research methods in education. New York: Routledge.

Costa, P. T., Jr., \& McCrae, R. R. (1992). NEO PI-R professional manual. Odessa, FL: Psychological Assessment Resources.

Cronbach, L. J. (1951). Coefficient alpha and the internal structure of tests. Psychometrika, 16, 197-334. http://dx.doi.org/10.1007/BF02310555

Datu, J. A., Valdez, J. P., \& Datu, N. D. (2012). Does Facebooking make us sad? Hunting relationship between Facebook use and depression among Filipino adolescents International Journal of Research Studies in Educational Technology, 1(2), 83-91. http://dx.doi.org/10.5861/ijrset.2012.202

Datu, N. D., Datu, J. A., \& Rungduin, D. (2013). Personality differences of college students with public and private Facebook profile: A big five model viewpoint. Advanced online publication. Retrieved April 9, 2013. http://dx.doi.org/10.5861/ijrsp.2013.250

Davies, J. (2011). Facework on Facebook as a new literacy practice. Computers \& Education. Advanced online publication. Retrieved November 25, 2011. http://dx.doi.org/10.1016/j.compedu.2011.11.007

Facebook. (2011). Facebook statistics. Retrieved December 25, 2011, from http://www.facebook.com/press/info.php?statistics

Fiske, D. W. (1949). Consistency of the factorial structures of personality ratings from different sources. Journal of Abnormal Social Psychology, 44, 329-344. http://dx.doi.org/10.1037/h0057198 
A study on the relationship of Facebook and EFL learners' personality

Goldberg, L. R. (1990). An alternative "description of personality": The big-five factor structure. Journal of Personality and Social Psychology, 59, 1216-1229. http://dx.doi.org/10.1037/0022-3514.59.6.1216

Goldberg, L. R. (1992). The development of markers for the big-five factor structure. Psychological Assessment, 4, 26-42. http://dx.doi.org/10.1037/1040-3590.4.1.26

Goldberg, L. R. (1993). The structure of phenotypic personality traits. American Psychologist, 48(1), 26-34. http://dx.doi.org/10.1037/0003-066X.48.1.26

Goldberg, L. R., \& Kilkowski, J. M. (1985). The prediction of semantic consistency in self-descriptions: Characteristics of persons and of terms that affect the consistency of responses to synonym and antonym pairs. Journal of Personality and Social Psychology, 48, 82-98. http://dx.doi.org/10.1037/0022-3514.48.1.82

Guildford, J. P. (1959). Personality. New York: McGraw-Hill.

Hew, K. F. (2011). Students' and teachers' use of Facebook. Computers in Human Behavior, 27(2), $662-676$. http://dx.doi.org/10.1016/j.chb.2010.11.020

Hogan, R., \& Hogan, J. (1992). Hogan personality inventory manual. Tulsa, OK: Hogan Assessment Systems.

Hogan, R., Johnson, J., \& Briggs, S. (Eds.). (1997). Handbook of personality psychology. California: Academic Press.

John, O. P. (1989). Towards a taxonomy of personality descriptors. In D. M. Buss \& N. Cantor (Eds.), Personality psychology: Recent trends and emerging directions (pp. 261-271). New York: Springer-Verlag. http://dx.doi.org/10.1007/978-1-4684-0634-4_20

John, O. P. (1990). The "Big Five" factor taxonomy: Dimensions of personality in the natural language and questionnaires. In L. A. Pervin (Ed.), Handbook of personality: Theory and research (pp. 66-100). New York: Guilford Press.

John, O. P., Donahue, E. M., \& Kentle, R. L. (1991). The big five inventory: Versions 4a and 54. Berkeley, CA: University of California, Berkeley, Institute of Personality and Social Research.

John, O. P., \& Srivastava, S. (1999). The big five trait taxonomy: History, measurement, and theoretical perspectives. In L. A. Pervin \& O. P. John (Eds.), Handbook of personality: Theory and research (pp. 102-138). New York: Gilford.

Karim, N. S. A., Zamzuri, N. H. A., \& Nor, Y. M. (2009). Exploring the relationship between Internet ethics in university students and the big five model of personality. Computers \&amp; Education, 53(1), 86-93.

Kok, A. (2008). Metamorphosis of the mind of online communities via e-learning. Instructional Technology and Distance Learning, 5(10), 25-32.

Liccardi, I., Ounnas, A., Pau, R., Massey, E., Kinnunen, P., Lewthwaite, S., et al. (2007). The role of social networks in students' learning experiences. ACM SIGCSE Bulletin, 39(4), 224-237. http://dx.doi.org/10.1145/1345375.1345442

McCrae, R. R., \& Costa, P. T., Jr. (1996). Toward a new generation of personality theories: Theoretical contexts for the five factor model. In J. Wiggens (Ed.), The five factor model of personality (pp. 51-87). New York: Guilford Press.

McCrae, R. R., \& Costa, P. T., Jr. (2003). Personality in adulthood, a five-factor theory perspective. New York: Guilford Press. http://dx.doi.org/10.4324/9780203428412

McCrae, R. R., \& Costa, P. T., Jr. (2010). NEO inventories: Professional manual. Lutz, FL: Psychological Assessment Resources.

McCrae, R. R., Costa, P. T., Jr., \& Martin, T. A. (2005). The NEO-PI-3: A more readable revised NEO personality inventory. Journal of Personality Assessment, 84(3), 261-270. http://dx.doi.org/10.1207/s15327752jpa8403_05

McCrae, R. R., \& John, O. P. (1992). An introduction to the five-factor model and its applications. Journal of Personality, 60, 175-215. http://dx.doi.org/10.1111/j.1467-6494.1992.tb00970.x

Merriam, S. B. (1998). Qualitative research and case study applications in education. San Francisco: Jossey Bass.

Nadkarni, A., \& Hofmann, S. G. (2012). Why do people use Facebook? Personality and individual differences, 52(3), 243-249. http://dx.doi.org/10.1016/j.paid.2011.11.007

Norman, W. T. (1963). Toward an adequate taxonomy of personality attributes: Replicated factor structure in peer nomination personality ratings. Journal of Abnormal and Social Psychology, 66, 574-583. http://dx.doi.org/10.1037/h0040291

Nunnally, J. C. (1970). Introduction to psychological measurement. New York: McGraw-Hill.

Ohler, J. B. (2010). Digital community digital citizen. Thousand Oaks, California: Corwin.

Personality. (2012). Merriam-Webster.com. Retrieved July 15, 2012, from http://www.merriam-webster.com/dictionary/personality

Pervin, L. A., \& John, O. P. (Eds.). (1999). Handbook of personality: Theory and research. New York: Gilford. 
Wang, C. Y. \& Ching, G. S.

Potkay, C., \& Allen, B. (1986). Personality: theory, research, and applications. California: Brooks/Cole.

Rammstedt, B., \& John, O. P. (2007). Measuring personality in one minute or less: A 10-item short version of the big five inventory in English and German. Journal of Research in Personality, 41(1), 203-212. http://dx.doi.org/10.1016/i.jrp.2006.02.001

Reinhardt, J., \& Zander, V. (2011). Social networking in an intensive English program classroom: A language socialization perspective. CALICO, 28(2), 326-344.

Ross, C., Orr, E. S., Sisic, M., Arseneault, J. M., Simmering, M. G., \& Orr, R. R. (2009). Personality and motivations associated with Facebook use. Computers in Human Behavior, 25(2), 578-586. http://dx.doi.org/10.1016/j.chb.2008.12.024

Rouis, S., Limayem, M., \& Salehi-Sangari, E. (2011). Impact of Facebook usage on students' academic achievement: Role of self-regulation and trust. Global Journal of Engineering Education, 9(3), 961-994.

Ryan, T., \& Xenos, S. (2011). Who uses Facebook? An investigation into the relationship between the Big Five, shyness, narcissism, loneliness, and Facebook usage. Computers in Human Behavior, 27(5), 1658-1664. http://dx.doi.org/10.1016/j.chb.2011.02.004

Schmitt, D. P., Allik, J., McCrae, R. R., \& Benet-Martínez, V. (2007). The geographic distribution of big five personality traits: Patterns and profiles of human self-description across 56 nations. Journal of Cross-Cultural Psychology, 38, 173-212. http://dx.doi.org/10.1177/0022022106297299

Thomas, M. (Ed.). (2011). Digital education: Opportunities challenges, and responsibilities. New York: Palgrave Macmillan.

Tupes, E. C., \& Christal, R. E. (1961). Recurrent personality factors based on trait ratings TX: Aeronautical Systems Division, Personnel Laboratory.

Wang, B. T., Sheu, T. W., \& Masatake, N. (2011). Evaluating the English-learning of engineering students using the Grey S-P chart: A Facebook case study in Taiwan. Global Journal of Engineering Education, 13(2), 51-56.

Yin, R. K. (1984). Case study research: Design and methods. Newbury Park, CA: Sage. 